ARTICLE INFO

Received

July 20, 2021

Revised

September 24, 2021

Accepted

September 27, 2021

Published

November 05, 2021

*Corresponding author

Dorcas N. Kalele

E-mail

doriskalele@gmail.com

Keywords

Climate Variability

Climate change

Perception

Adaptation

Vulnerable

Adaptive capacity

How to cite

Kalele DN, Oludhe C, Onono

JO, Ogara WO. Historical

climatic trends and

smallholder farmers'

perceptions of climate variability and change in arid and semi-arid lands of Kenya.

Sci Lett 2021; 9(3):95-109
Open Access

\section{Historical Climatic Trends and Smallholder Farmers' Perceptions of Climate Variability and Change in Arid and Semi-Arid Lands of Kenya}

Dorcas N. Kalele ${ }^{*}$, Christopher Oludhe ${ }^{1,2}$, Joshua O. Onono ${ }^{1}$, William O. Ogara ${ }^{1}$

${ }^{1}$ Institute for Climate Change and Adaptation, University of Nairobi, PO Box 3019700100, Nairobi, Kenya

2 Department of Meteorology, University of Nairobi, PO Box 30197-00100, Nairobi, Kenya

\section{Abstract}

This article presents an overview of smallholder farmers' perceptions of climate variability and change in synchrony with historical climate trends in Machakos County, Kenya. Farmers' perceptions were obtained using focus group discussions and household interviews. Monthly rainfall and temperature (minimum and maximum) data for the period of 1983-2014 were obtained and used in the analysis. The interview data were analyzed using descriptive statistics while data from the focus group discussions were analyzed using qualitative content analysis. The Mann-Kendall test and linear regression analysis were used to detect statistically significant climate trends. Meteorological data provided some evidence to support farmers' perceptions of changes in rainfall and temperature. The MannKendall test revealed statistically significant rainfall and temperature trends. The linear regression analysis showed increasing trends for both rainfall and temperature. Most farmers (77.7\%) perceived decreasing amounts of seasonal rainfall contrary to analyzed seasonal rainfall trends, which showed an increase in seasonal rainfall. The experienced changes and variations in rainfall and temperature expose the farming systems to climate change risks. To support smallholder farmers in managing the increasing climate change risks, there is a need to enhance their adaptive capacity through effective adaptation planning and implementation. 


\section{Introduction}

Climate change (CC) is one of the most composite environmental and societal challenges with considerable drawbacks to economic sectors, which mainly depend on natural resources and weather parameters such as livestock, fisheries, agriculture, forestry and tourism [1,2]. The CC is notably affecting the agriculture sector, which is a focal economic pillar and a prime contributor to the gross domestic products for most of the developing world. This has led to undermine global efforts towards poverty alleviation, curbing food insecurity, while also negatively impacting overall development efforts [3]. The agricultural systems, particularly in sub-Saharan Africa are facing increased vulnerability to $\mathrm{CC}$ impacts since most producers are smallholder farmers whose livelihood mainly depends on rainfed agriculture [4-7]. The vulnerability of the smallholder farming systems is intensified by the fragmentation in land sizes, deteriorating soil health, high poverty levels, inadequate expertise and low technological and infrastructural development [8-10].

The predictions of Intergovernmental Panel on Climate Change (IPCC) show that the Africa region will be the most affected by $\mathrm{CC}$ due to changes in both mean rainfall and temperature as well as increased variability associated with both [1]. The forecasts further show that there is a shift in both short and long-term trends of rainfall and temperature parameters, which calls for an understanding of the trends, especially in the arid and semi-arid lands (ASALs) where the parameters are becoming increasingly unpredictable. A recent assessment by the IPCC shows that the continued increase in temperature will pose more risks in the sub-Saharan Africa, especially in countries like Kenya which lies along the equator $[4,11]$. In the last few years, Kenya has faced an increase in unpredictable rainfall patterns coupled with long periods of often higher than normal temperatures as well as rainfall, which has led to reduced crop productivity aggravating food insecurity for most households. Various studies have investigated the variability and historical trends of climate variables in Kenya. An assessment in the East of Kenya's ASALs showed that there have been discrepancies in seasonal and inter-annual rainfall and temperature data over time. The assessment showed a notable increase of $1^{\circ} \mathrm{C}$ and $0.3^{\circ} \mathrm{C}$ for year-to-year variations in both mean annual minimum temperature $\left(\mathrm{T}_{\min }\right)$ and maximum temperature $\left(\mathrm{T}_{\max }\right)$, respectively for 31-years [12, 13]. Several authors have pointed to significant downward trends in rainfall in East Africa, especially in the March-April-May (MAM) seasonal totals $[14,15]$. Some regions of Kenya have reported variations in spatial rainfall trends with insignificant variability in the MAM season [16]. Since the 1960s, rainfall observations for Kenya do not show statistically significant trends [17]. However, an analysis of rainfall and temperature trends over the last 50 years (19602009) showed significant rainfall trends with a projected decrease during the MAM by more than $100 \mathrm{~mm}$ until 2025 [13].

Despite the climate changes (CCs), smallholder farmers in many parts of Africa don't have access to relevant and accurate climate information [18], which hinders understanding of climatic patterns at the local level [19]. Local communities' perceptions of CCs can provide an effective strategy to complement the insufficient meteorological data at the local level [19]. Indigenous knowledge is increasingly recognized as an important component for effective climate change adaptation [20] that functions alongside scientific strategies for sustainable solutions to CC impact $[21,22]$. This is in view that most rural farmers tend to live in the same locality where they were born, which makes them a 'living' record of experienced changes in the local climate [23]. Understanding local peoples' perceptions of climate parameters and relating their perceptions to historical climate data is thus important for better planning of adaptation options to the community [22]. Knowledge of farmers' perception of CC thus deepens the understanding of the realities of $\mathrm{CC}$ at the local level, which is critical for effective adaptation as well as policy formulation and implementation [14, 22, 24, 25]. On the contrary, most policies of adaptation are formulated at the national level without taking cognizance of farmers' indigenous knowledge and what solutions are already available in the local context.

This study took into consideration that several studies have been conducted to investigate historical climate trends in Kenya [12, 26-28], review climate change impacts as well as analyze smallholder farmers' perceptions and adaptation of CC [28-31]. The study also considered that limited research has attempted to document smallholder farmers' perceptions of climate variability and changes and link the perceptions to historical climate trends in Kenya [29, 32, 33]. This article, 
therefore, aimed to add to the body of existing knowledge while also making comparisons with other similar studies. The findings of this study will guide the integration of knowledge and experience from smallholder farmers in the formulation and implementation of CC policies, which will offer an opportunity for viable adaptation options in the ASALS. The broad objective of the study was to explore smallholder farmers' perceptions of CC and variability and to validate the farmers' understanding with the historical climate data from the meteorological records in the study area. The study brings in new knowledge on understanding smallholder farmers' perceptions of CC and how this relates to historical climate trends considering the increasing uncertainty associated with changing weather patterns in Kenya. Understanding local farmers' perceptions of CC in their farming systems will aid in better adaptation planning towards sustainable food security and improved livelihoods in Kenya's ASALs. The study sought to address three research questions: (1) is there an indication of climate variability and change in the Yatta sub-county in Kenya? (2) What is the smallholder farmers' perception of climate variability and change in the Yatta sub-county? and (3) How do farmers' perceptions of climate change and variability compare with the historical climate data trends?

\section{Materials and Methods}

\section{Description of the study area}

The study was undertaken in the villages of Yatta sub-county, Machakos County, which is in Eastern Kenya (Fig. 1). The county lies in Kenya's ASALs whose climate is mostly hot and dry in most part of the year. It stretches from latitudes $0^{\circ} 45^{\prime}$ South to $1^{\circ} 31^{\prime}$ 'South and longitudes $36^{\circ} 45^{\prime}$ East to $37^{\circ} 45^{\prime}$ East. Topographically, the area has an altitude of 1,000-1,600 meters above sea level. The county consists of eight administrative sub-counties: Masinga, Yatta, Kangundo, Machakos town, Matungulu, Kathiani, Mavoko and Mwala. The study purposefully selected the Yatta sub-county because it's the driest and is dominated by smallholder farmers who depend on rainfed agriculture for livelihoods; hence, facing increasing vulnerability to extreme climatic events [34]. The area experiences low and unpredictable rainfall with less than $500 \mathrm{~mm}$ of annual rainfall with spatial and temporal variations. The rainfall pattern is bimodally distributed in two rainy seasons [34]. The first season occurs in March, April and May (MAM season) and is termed as the long rains while the second season occurs in October, November and December (OND season) and is termed as the short rains. Over the years, the main crop production season has shifted from the long rains to the short rains with little production during the long rains. The temperature has been on the increase ranging between $25-29^{\circ} \mathrm{C}$ thus aggravating inadequate rains and disappearance of seasonal streams, which has aggravated water shortage in the area [34].

\section{Data sources}

Both primary and secondary data sources were used. The primary data were both qualitative and quantitative and were collected using focus group discussions (FGDs) and household interviews, respectively. The secondary data were a combination of two data sets: first in situ climate datasets (rainfall and temperature) obtained from the Kenya Agro-Meteorological Department station situated at the Kenya Agricultural and Livestock Research Organization, Katumani in Machakos county, and second the satellite rainfall and temperature available in the Geospatial climate data (GeoCLIM) software. Additional secondary data were obtained through desk and literature review of scientific publications, assessments, and policy reports to complement the primary data sources.

\section{Sample size and sampling procedure}

A multi-stage sampling with a combination of purposive and simple random sampling procedures was used. The Yatta sub-county was purposively selected in the first stage of sampling, out of the eight sub-counties based on its extensive vulnerability to drought and additionally, the subcounty was characterized based on its five administrative wards. In the subsequent stage, Ndalani ward was purposively selected from the five wards owing to its ease of accessibility and insufficient documentation of CC information for the area. The Ndalani ward is composed of two locations; Mavoloni and Ndalani, which consist of three and two sub-locations, respectively. In the final sampling stage, three sub-locations (Ndalani, Kwa-Ndolo and Mavoloni) were selected out of the five based on the fact that they widely constituted smallholder farmers whose livelihood depends on rainfed agriculture. A list of the villages in the chosen sub-locations was used to represent the 


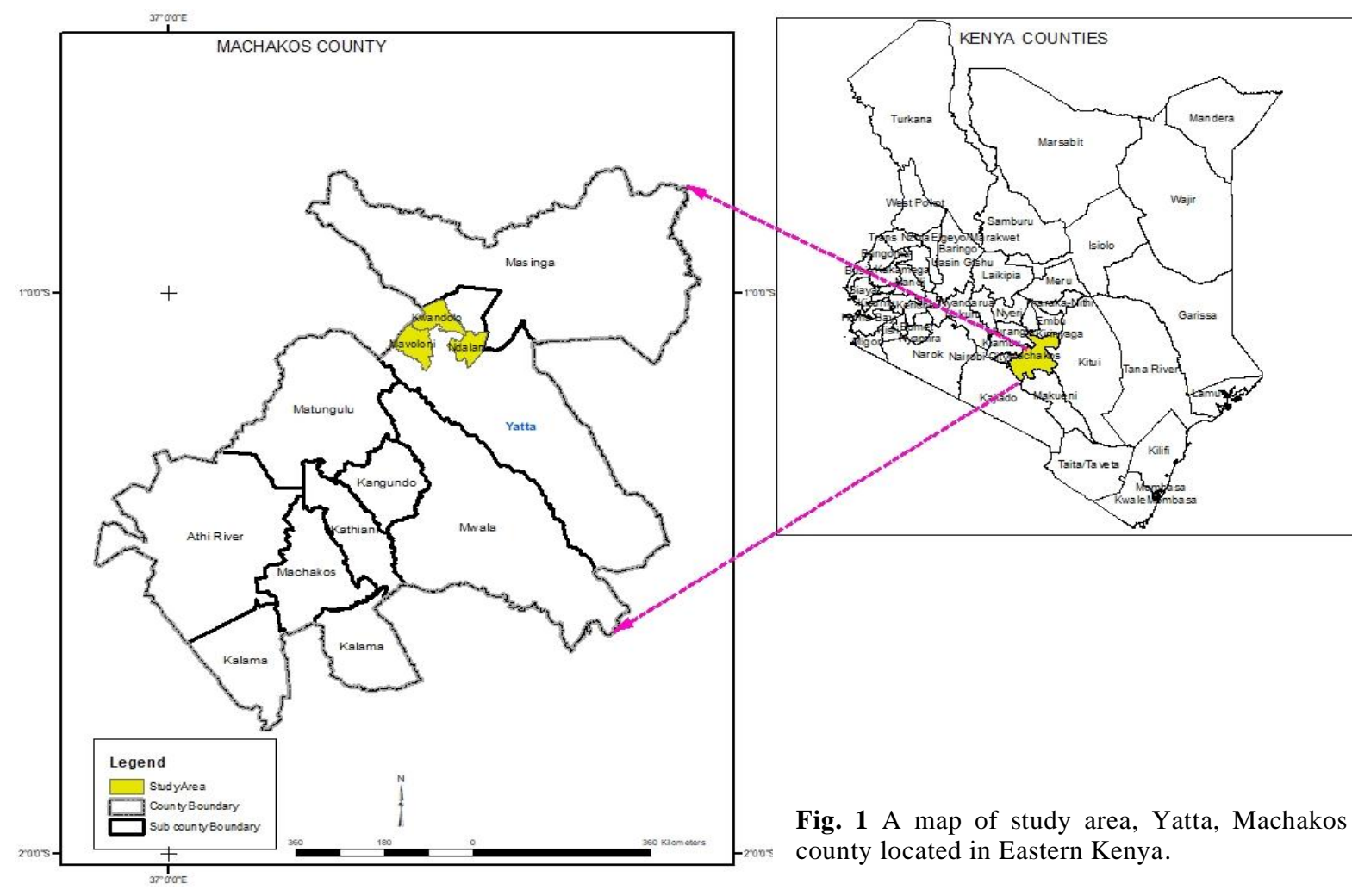

sampling frame from which 46 villages out of an entire 88 were selected using simple random sampling. The representative sample size for the household interviews was computed using a simplified formula by Yamane [36]. The sample size was calculated from a given finite population (P) at 95\% confidence level and 5\% degree of variability using equation 1 below.

$n=\frac{N}{1}+N_{e}^{2}$

eq. 1

Where $\mathrm{n}=$ optimum sample size; $\mathrm{N}=$ population size; $\mathrm{e}=$ probability of error $=0.05$

An optimum sample size of 384 respondents was obtained. Though, to provide for non-responses and poor data taking, a larger sample size of 400 households was considered. The interviews were then conducted with the 400 households from the selected villages while aiming at smallholder farmers who practiced mixed farming. Eight FGDs were conducted, with the discussants purposefully selected using local contacts to constitute farmers inherent to the community. Each FGD group consisted of ten participants of both men and women aged over 30 years and could thus offer valued intuitions on how farming methods and climate in the locality had changed over the years.

\section{Data collection methods}

The primary data was attained using a mixedmethod approach, which integrated quantitative data from household interviews triangulated with qualitative data from the FGDs. The interviews were conducted using a structured questionnaire consisting of closed-ended and Likert-scale questions. The closed-ended questions were used to assess household demographics, socio-economic characteristics and agriculture variables. The Likert-scale questions were used to assess farmers' perceptions of climate variability and change using a set of five-point Likert-scale questions (where 1= strongly disagree, $2=$ disagree, $3=$ not sure, $4=$ agree, $5=$ strongly agree). The respondents were asked to indicate any changes they had noted in climate variability and change indicators, seasonal rainfall and temperature over the last five years. A structured guide divided into sections with questions corresponding to those in the structured questionnaire was used to lead the FGDs. The FGDs were meant to give a detailed overview of farmers' perceptions of climate variability and change and its effects on the farming systems and livelihood. Before administration, the research instrument was validated through pilot testing with 20 farmers who were selected from four villages, 
while the FGD guide was given to experts for their review and feedback. Any ambiguity, inappropriate variables and indicators were noted and adjusted accordingly. The villages where farmers were included in the pre-test were excluded from the actual survey and more analysis. The climate data used was based on a gridded monthly rainfall $(\mathrm{mm})$, and minimum $\left(\mathrm{T}_{\min }\right)$ and maximum $\left(\mathrm{T}_{\max }\right)$ temperature $\left({ }^{\circ} \mathrm{C}\right)$ for 32 years $(1983-2014)$. The GeoCLIM software was used to extract the satellite data sets from the raster file, which was then ground and blended with the in-situ data sets to obtain more accurate gridded data, at a horizontal grid spatial resolution of $5 \mathrm{~km}$ by $5 \mathrm{k} \mathrm{m}$.

\section{Data processing and analysis}

The data analysis methods used were descriptive analysis, qualitative content analysis, trend analysis and coefficient of variation.

\section{Descriptive analysis}

The structured questionnaire data were coded and analyzed using the Statistical Package for Social Scientists (SPSS) Version 23 and MS Excel Tool Pak. Descriptive statistics of the main variables (socio-demographic and agriculture profile) were calculated and displayed using frequency distribution, percentages and measures of central tendency (mean and mode). The mean obtained from each specific Likert item gave a general respondents' perception of the variable. The mean was complemented by the mode to attain a general perception of the respondents, while taking note of the majority perception. For instance, a Likert item with a mean of 4 and a mode of 4 implied that the general respondents" perception was "agree" with most respondents also indicating "agree". Cumulative figures for "agree" and "strongly agree" were used to express the utmost important variables for the Likert item results.

\section{Qualitative content analysis}

Transcription of the FGDs audio files was done and each script was confirmed by comparing field notes to the transcribed scripts. Data entry, cleaning and coding were done using emergent themes and the data were analyzed via qualitative content analysis. The main subjects in the entire transcripts were additionally coded into sub-themes, which were clustered together using comparable topics. This was followed by a score of the clusters that had comparable themes/sub-themes. The FGDs data have been demonstrated using direct quotations to depict discussants' opinions and experiences which display the authenticity of the findings [36].

\section{Trend analysis}

Parametric and non-parametric methods were used to detect the presence of trends in rainfall and temperature variables over the analysis period (1983-2014) [37, 38].

Linear regression is a parametric test used to verify the magnitude, direction and significance of climate trends. A linear regression model was fitted to generate a trend line [39] and changes in temperature and rainfall were described using the trend line equation:

$Y=\beta_{0}+\beta_{1} X$

eq. 2

Where "Y" represents the value of temperature $\left({ }^{\circ} \mathrm{C}\right)$ or rainfall $(\mathrm{mm})$, " $\beta_{1}$ " represents the slope, hence, the rate of change of the climate variability over the period and " $\beta_{0}$ " represents the intercept on the $y$ axis. The slope was used as a measure of how many units (rate of increase/decrease) the rainfall or temperature had gone up or down for every year or season. A negative slope value implied a decrease in the amount of rainfall/temperature while a positive value indicated an increase in the amount of rainfall/temperature.

The Mann-Kendal (MK) test is a nonparametric method that is used to detect changes (monotonic upward or downward trends) in seasonal climate (temperature and rainfall trends). The MK test is an exceptional tool that is used for detecting trends because data doesn't have to be normally distributed and thus it is less affected by outliers and other types of non-normality [37, 40, 41]. The MK test is based on the calculation of Kendall's tau (a measure of association between annual rainfall/temperature data for two consecutive years) and it searches for a trend in a time series without showing whether the trend is linear or non-linear [40]. The MK test was run at $5 \%$ significance level on time series data and the resulting MK test statistic (S) was used to express the strength of the trend and whether it was increasing or decreasing [40, 41]. The null hypothesis $\left(\mathrm{H}_{0}\right)$ assumed that there was no trend which was tested against the alternative hypothesis $\left(\mathrm{H}_{1}\right)$ assuming that there was a trend (increasing or decreasing) in temperature and rainfall amounts over time. If the computed $P$-value was less than the significance level alpha $(\alpha=0.05)$, the null hypothesis was rejected thus inferring the existence 
of significant trends in the time series and vice versa.

The coefficient of variation $(\mathrm{CV})$ is calculated as the ratio of the standard deviation to the mean of a dataset over a given period. The $\mathrm{CV}$ was computed to show the interannual rainfall variability in this study. A CV less than $20 \%$ is an indicator of less variable rainfall, a CV of $20 \%$ to $30 \%$ indicates a moderately variable rainfall while a $\mathrm{CV}>30 \%$ is an indicator of large rainfall variability [42].

\section{Results and Discussion}

\section{Socio-demographics and household characteristics}

Results of socio-demographic and household characteristics showed that female respondents were slightly higher $(53.7 \%)$ in numbers than male $(46.3 \%)$ respondents (Table 1). Most of the households were headed by males $(76.6 \%)$ while households headed by females represented $23.4 \%$. The age of most $(34 \%)$ of the respondents was between 25-34 years, with 25\% aged between 3544 years, while those aged over 55 years represented $21 \%$. The respondents who had lived within the locality for more than 30 years represented $36.44 \%$, while only a small percentage $(1.41 \%)$ had lived in the area for 5-10 years. Theduration an individual has lived in an area is a vital component, especially in studies with smallholder farmers as the farming experience and knowledge on how $\mathrm{CC}$ has transformed is accumulated over the years.

\section{Agriculture profile}

Most of the respondents (77.4\%) practiced rain-fed agriculture, $17.51 \%$ integrated both rainfed and irrigated farming while the smallest percentage (3.95\%) practiced irrigated farming (Table 2). Among different crops, maize (Zea mays) was the major crop $(94.92 \%)$ grown followed by beans (Phaseolus vulgaris) (66.38\%), cowpeas (Vigna unguiculata) $(64.12 \%)$, pigeon peas (Cajanus cajan) $(47.74 \%)$ and green grams (Vigna radiata) (28.53\%). Minor crops grown included millet (Pennisetum glaucum) (12.15\%), sorghum (Sorghum bicolor) (5.37\%), sweet potatoes (Ipomoea batatas) (8.47\%), Dolichos (Lablab purpureus) $(5.08 \%)$ and cassava (Manihot esculenta) (0.85\%) (Fig. 2)

\section{Farmers' perception of climate change indicators}

All the CC indicator variables recorded a mean of approximately 4 as well as a mode of 4 . This shows that the majority of the respondents agreed that the $\mathrm{CC}$ indicators evaluated had been experienced in the study area over the last five years. Most respondents $(77.68 \%)$ perceived decreasing trends in seasonal rainfall by $79.7 \%$ indicating an increase in food insecurity. Moreover, most respondents

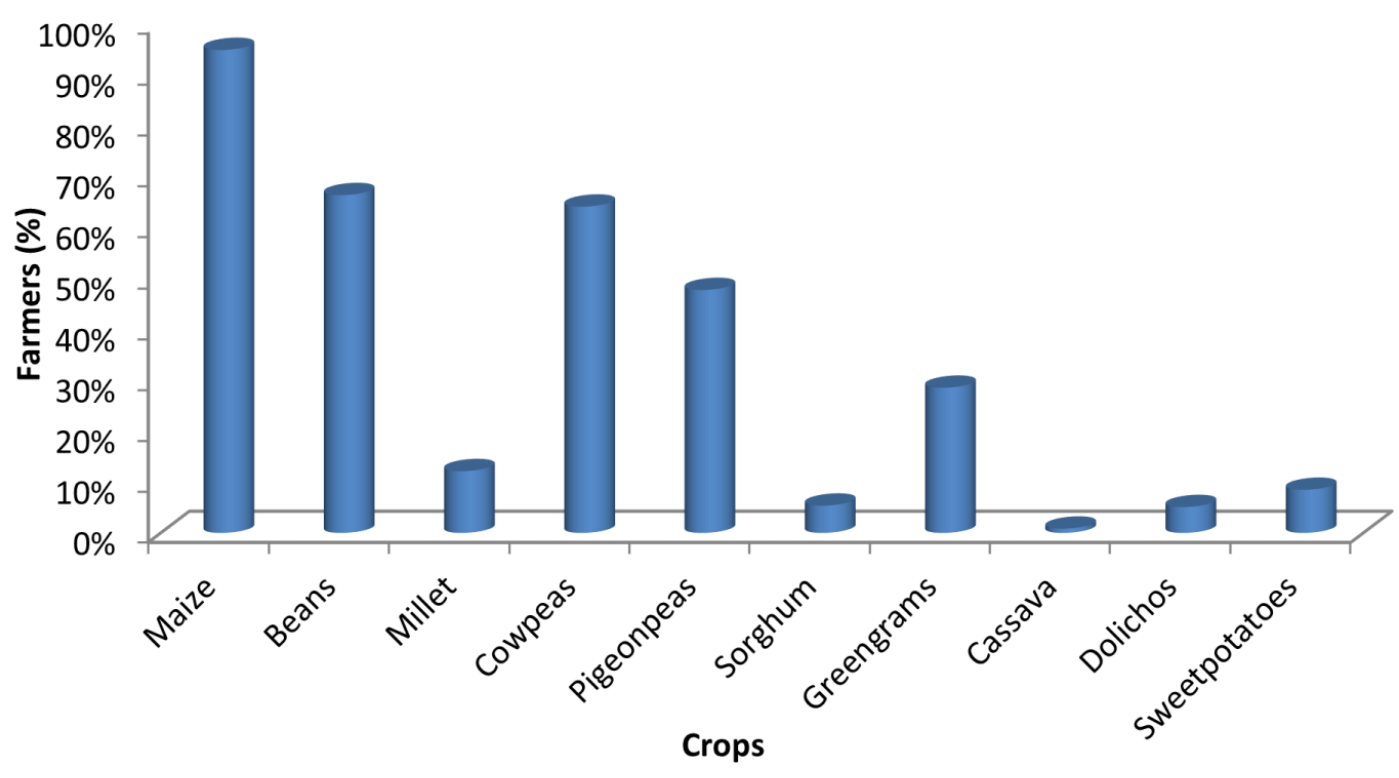

Fig. 2 The types of crops grown by farmers in the Yatta, Machakos county, Kenya. 
Table 1 Socio-demographics and household characteristics of farmers in Yatta, Machakos county, Kenya.

\begin{tabular}{|c|c|c|}
\hline Variable & Response & Percentage $(\%) ; n=354$ \\
\hline \multirow{2}{*}{ Gender } & Male & 46.3 \\
\hline & Female & 53.7 \\
\hline \multirow{2}{*}{ Gender of household head } & Male & 76.6 \\
\hline & Female & 23.4 \\
\hline \multirow{5}{*}{ Age (years) } & $15-24$ & 6 \\
\hline & $25-34$ & 34 \\
\hline & $35-44$ & 25 \\
\hline & $45-54$ & 13 \\
\hline & $>55$ & 21 \\
\hline \multirow{5}{*}{ Education level } & Primary school & 34.5 \\
\hline & Secondary School & 34.2 \\
\hline & Tertiary / College & 18.4 \\
\hline & University & 5.6 \\
\hline & No formal Education & 7.3 \\
\hline \multirow{8}{*}{ main source of income } & Crop farming & 75.99 \\
\hline & Livestock farming & 5.93 \\
\hline & Off-farm employment & 1.98 \\
\hline & Government employment & 1.41 \\
\hline & Business & 12.43 \\
\hline & Pension & 0.56 \\
\hline & Government Welfare & 0.85 \\
\hline & Other & 0.85 \\
\hline \multirow{3}{*}{ Family size } & $1-3$ & 12.1 \\
\hline & $4-6$ & 37.29 \\
\hline & $>7$ & 50.56 \\
\hline \multirow{7}{*}{ Years lived in the community } & $1-5$ years & 7.34 \\
\hline & $5-10$ years & 1.41 \\
\hline & $10-15$ years & 13.28 \\
\hline & $15-20$ years & 13.84 \\
\hline & $20-25$ years & 16.10 \\
\hline & $25-30$ years & 11.58 \\
\hline & $>30$ years & 36.44 \\
\hline
\end{tabular}

$(81.64 \%$ and $81.92 \%)$ perceived changes in rainfall timings and occurrence of unpredictable rainfall patterns over the past five years respectively. The change in rainfall timings and increase in food insecurity during the FGDs and discussants reported that:

"Before we used to have some rain in midFebruary, which boosted the emergence of green grass for our livestock. The MAM rain came in the first week of March and continued until May, we had plenty of harvest in June and July. Nowadays the long rain comes in late March, sometimes even in mid-April and our crops produce less. In the 1980s, we had rain in September before the actual rain in early October and by early December our beans were already mature."

Moreover, most of the respondents $(93.61 \%)$ perceived an increase in drought incidences, while $61.02 \%$ noted that seasonal rivers had disappeared over time. Decreased rainfall amounts for extended periods translate to drought, which poses a threat to the agricultural systems. Another outcome associated with a decrease in seasonal rainfall is the drying of seasonal rivers, which translates to water shortage for both humans and animals. The disappearance of seasonal rivers, increase in drought incidences and reduced crop harvest was supported by the FGDs discussants who reported that:

"Before, our rivers used to fill and overflow, which doesn't happen nowadays, in most cases. The rainfall we experience is scarcely enough to bring enough crop harvests and rains are no longer reliable and have become shorter than before."

Similar findings were reported by Chepkoech et al. [29], where farmers in the humid zones of Kakamega County in Kenya had experienced the unpredictable onset and patterns in the seasonal rainfall. The findings of this study concur with other results, which have shown that Kenya's 
Table 2 Type of crop farming $(n=354)$ in Yatta, Machakos county, Kenya.

\begin{tabular}{lcc}
\hline Type of crop farming & Frequency & Percentage \\
\hline Rainfed crop farming & 274 & $77.40 \%$ \\
Irrigated crop farming & 14 & $3.95 \%$ \\
Rainfed \& irrigated & 62 & $17.51 \%$ \\
crop farming & 4 & $1.13 \%$ \\
None &
\end{tabular}

ASALs have continually experienced erratic rainfall patterns coupled with changes in rainfall timings shown by late-onset and early cessation of seasonal rains [29, 33, 43]. The results are also in agreement with other findings, which have shown that farmers in Kenya's ASALs have continued to experience cases of unpredictable rainfall patterns, reduced seasonal rainfall and increasing cases of drought [11, 44-46].

\section{Farmers' perceptions of changes in seasonal rainfall}

Rainfall intensity and duration as well as rainfall onset and cessation were used to determine farmers' perception of changes in seasonal rainfall. Most of the respondents $(63.56 \%$ and $52.83 \%)$ perceived a decrease in the duration of short rains (OND) and long rains (MAM), respectively over the past five years (Table 4). On the other hand, the majority $(51.13 \%)$ respondents perceived that there was no increased intensity in the OND rains while $48.59 \%$ perceived increased intensity in the MAM rains over the past five years. The majority
(74.40\% and $69.49 \%$ ) of farmers perceived that the onset and cessation of seasonal rainfall had become quite unpredictable. The survey findings were verified during the FGDs, where cases of unpredictable and increased intensity of seasonal rainfall were reported:

"In the 1970s and 1980s, the MAM rains came in the first week of March and would last up to end of May but nowadays the rains start late sometimes in mid-April and last only for a month, hence, our crops hardly produce. The MAM rains have become quite intense over a short period, they carry soil away and sweep anything on the ground. In the 1980s, we relied on both the MAM and OND rains for successful crop harvest, in the 1990s the OND rains became more reliable than the MAM rains; lately, both showers of rain are no longer reliable and have become shorter than before, hence, we are so uncertain which rain to rely on for crop production."

Similar findings were obtained in the humid (Kakamega County) and semi-arid zones (Kajiado County) in Kenya, where cases of increased intensity and changes in onset and cessation of seasonal rainfall were reported [29]. Similar findings were also reported in semi-arid Highlands of Eastern Tigray, Northern Ethiopia, where farmers perceived increased rainfall intensity with late-onset and early cessation of seasonal rainfall in the past fifteen years [47]. Similar studies conducted in Tanzania [44, 48] showed that farmers had reported a shift in rainfall season with the onset

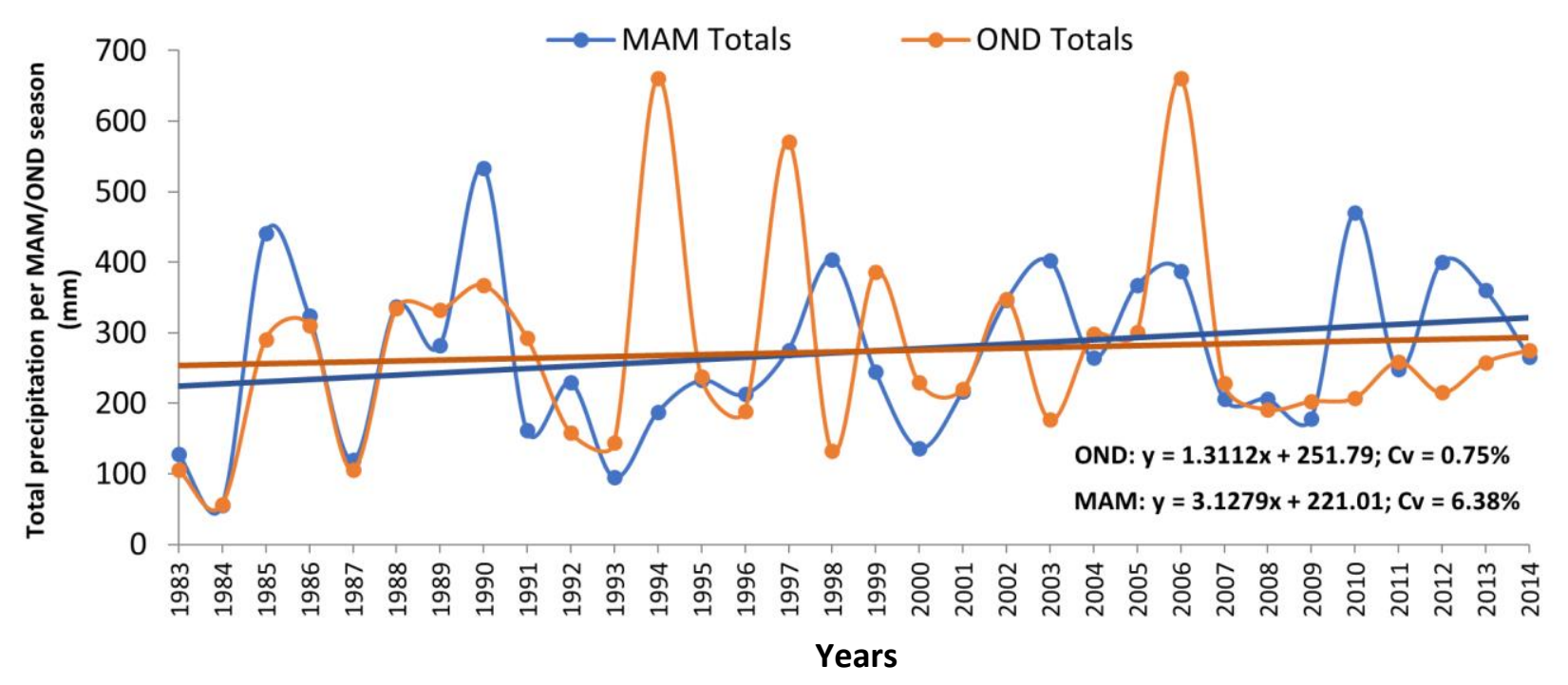

Fig. 3 Trends of total March-April-May (MAM) and October-November-December (OND) seasonal rainfall in Yatta, Machakos county, Kenya (1983-2014). 
of seasonal rainfall, changing from October/November to December/January, which had affected planning for their agricultural activities. Similar findings were reported also in Ghana, South Benin and Uganda [32, 49, 50].

\section{Variability and trends in seasonal rainfall}

The OND season recorded a slightly higher amount of rainfall than the MAM season during the analysis period (1983-2014) (Fig. 3). The highest amount of rainfall in the OND season was recorded in 1994, 1997 and 2006 with seasonal totals of $650.9 \mathrm{~mm}, 571 \mathrm{~mm}$ and $660.9 \mathrm{~mm}$, respectively. On the other hand, the lowest amount of rainfall was recorded in 1983, 1984 and 1998 with seasonal totals of $105.8 \mathrm{~mm}, 57 \mathrm{~mm}$ and $133 \mathrm{~mm}$, respectively. The highest amount of rainfall in the MAM season was recorded in 1985, 1990 and 2010 with seasonal totals of $441.6 \mathrm{~mm}, 533.7 \mathrm{~mm}$ and $470.7 \mathrm{~mm}$, respectively. On the other hand, the lowest amount of rainfall was recorded in 1984, 1987 and 1993 with seasonal totals of $55.4 \mathrm{~mm}$, $119.4 \mathrm{~mm}$ and $95.4 \mathrm{~mm}$, respectively. The difference in the highest and the lowest rainfall during the OND and MAM season was $603.9 \mathrm{~mm}$ and $778.3 \mathrm{~mm}$, respectively. Low rainfall variability was recorded in both seasons with the MAM season recording a higher variability $(\mathrm{CV}=$ $6.38 \%)$ than the OND season $(\mathrm{CV}=0.75 \%)$. The linear regression analysis showed positive slopes for both seasons with the MAM season showing a higher magnitude of increase $(3.13 \mathrm{~mm})$ compared to the OND season $(1.31 \mathrm{~mm})$. This suggests that the mean seasonal rainfall in the area portrayed increasing trends despite the low variability experienced over the years. Table 5 shows the trends observed in seasonal rainfall data using the Mann-Kendall test. Both the MAM and OND rainfall trends were statistically significant $(P<0.05)$.

Analysis of seasonal rainfall trends and variability conducted in this study is important because most farmers in the area depend on rainfed agriculture. Rainfall variability and changing trends have consequences on crop productivity, which impacts farmers' livelihoods [51]. The increase in seasonal variability and rainfall amounts in the MAM season confirms a report by Awuor [52], which indicates that in the Eastern province of Kenya, the MAM rains have become increasingly erratic, unreliable and more intense and last only for a shorter period. The increase in rainfall variability in terms of timing and amount:

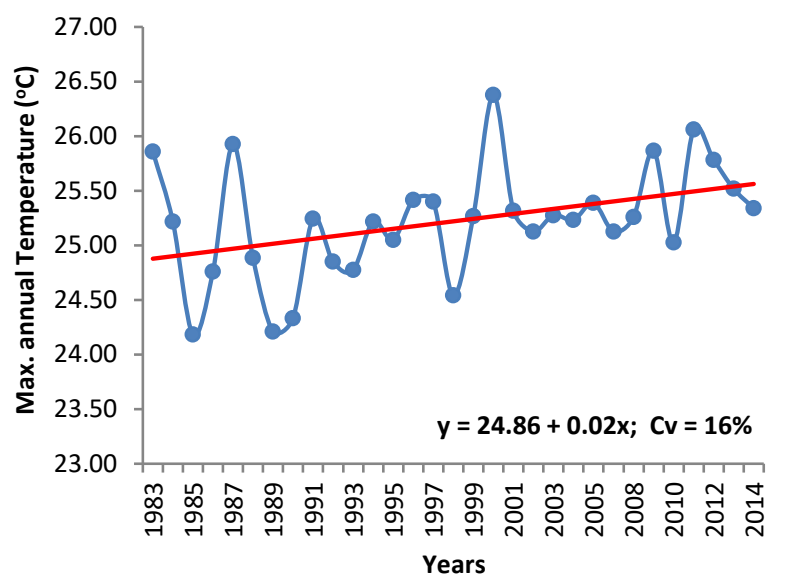

Fig. 4 Annual maximum temperature trends in Yatta Machakos county, Kenya (1983-2014).

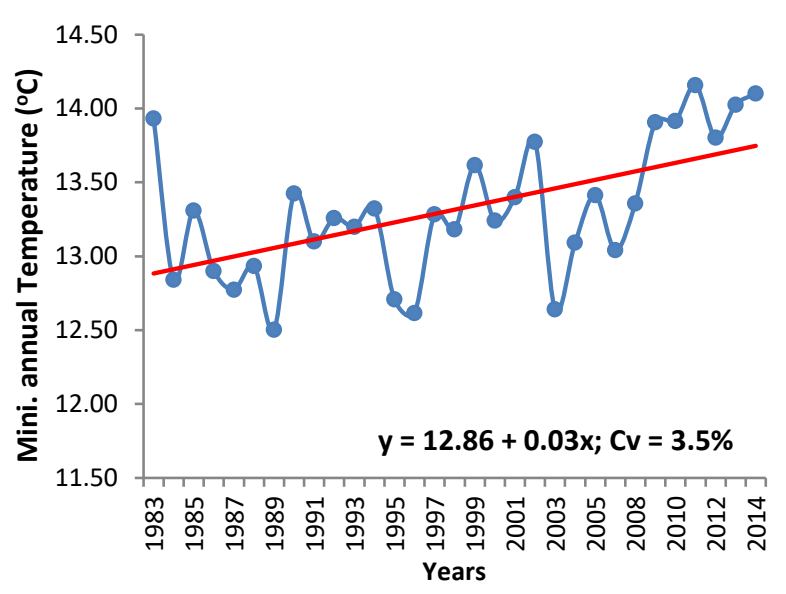

Fig. 5 Annual minimum temperature trends in Yatta Machakos county, Kenya (1983-2014).

including delays or shifts in the onset and/or cessation of both long and short rainy seasons, long or short dry spells and sometimes even loss of the entire season has led to increased climate risks in Kenya [53, 54]. Notably, the year 1984 was the driest having the lowest rainfall in the MAM season, which confirms similar findings by Recha et al. [26] who also reported that the MAM season in 1984 was the driest in the Tharaka Nithi District, Kenya.

\section{Farmers' perception of changes in temperature}

Most respondents agreed that there was an increase in daytime temperatures $(78.81 \%)$ and the number of hot days (65.26\%) over the past five years (Table 6 ). The two variables recorded a mode and mean of 4 , which shows that the majority of respondents had experienced an overall increase in daytime temperature and the number of hot days over the 
Table 3 Farmers' perception of climate variability and change indicators $(n=354)$.

\begin{tabular}{lccccccc}
\hline \multicolumn{1}{c}{ Indicator variables } & $\begin{array}{c}\text { Strongly } \\
\text { disagree }\end{array}$ & Disagree & $\begin{array}{c}\text { Not } \\
\text { sure }\end{array}$ & Agree & $\begin{array}{c}\text { Strongly } \\
\text { agree }\end{array}$ & Mean & Mode \\
\hline Increased drought incidences & 2.82 & 6.21 & 7.34 & $53.67 *$ & 29.94 & 4.16 & 4 \\
Change of rainfall timings & 1.13 & 7.91 & 9.32 & $50.00^{*}$ & 31.64 & 4.03 & 4 \\
Increased food insecurity & 4.80 & 6.78 & 8.76 & $40.40^{*}$ & 39.27 & 4.03 & 4 \\
Unpredictable rainfall patterns & 4.24 & 4.80 & 9.04 & $56.50^{*}$ & 25.42 & 3.94 & 4 \\
Decreased trends of seasonal rainfall & 3.67 & 7.06 & 11.58 & $55.65^{*}$ & 22.03 & 3.85 & 4 \\
Disappearance of seasonal rivers & 7.34 & 16.10 & 15.54 & $31.64 *$ & 29.38 & 3.60 & 4 \\
\hline
\end{tabular}

Note: values are expressed as percentage $(\%) ; *$ statistical significance at $P<0.05$

Table 4 Farmers' perception of changes in seasonal rainfall over the past five years $(n=354)$.

\begin{tabular}{|c|c|c|c|c|c|c|c|}
\hline Indicator variables & $\begin{array}{l}\text { Strongly } \\
\text { disagree }\end{array}$ & Disagree & $\begin{array}{l}\text { Not } \\
\text { sure }\end{array}$ & Agree & $\begin{array}{c}\text { Strongly } \\
\text { agree }\end{array}$ & Mean & Mode \\
\hline Unpredictable cessation of seasonal rainfall & 1.41 & 5.93 & 23.16 & $42.37 *$ & 27.12 & 4.00 & 4 \\
\hline Unpredictable onset of seasonal rainfall & 2.82 & 5.93 & 13.84 & $50.28 *$ & 27.12 & 3.93 & 4 \\
\hline Increased intensity of MAM rainfall & 10.17 & 20.90 & 20.34 & $29.10 *$ & 19.49 & 3.27 & 4 \\
\hline Increased occurrence of untimely rainfall & 9.04 & $29.66 *$ & 28.81 & 23.45 & 9.04 & 2.94 & 2 \\
\hline Increased duration of long rains (MAM) & 14.41 & $38.42 *$ & 12.99 & 25.42 & 8.76 & 2.76 & 2 \\
\hline Increased intensity of OND rainfall & 12.43 & $38.70 *$ & 20.62 & 20.62 & 7.63 & 2.72 & 2 \\
\hline Increased duration of short rains (OND) & 16.95 & $46.61 *$ & 19.21 & 13.28 & 3.95 & 2.41 & 2 \\
\hline
\end{tabular}

Note: values are expressed as percentage $(\%) ; *$ statistical significance at $P<0.05$; MAM $=$ March-April-May; OND $=$ October-November-December

past five years. On the other hand, most of the respondents disagreed that the number of cold days (50\%) had increased, and daytime temperatures had decreased (68.65\%), respectively. These results agree with the findings of Chepkoech et al. [29] who reported that farmers in the semi-arid area of Kajiado County, Kenya indicated very high temperatures during the day and very low during the night. Similar results in Kajiado County, Kenya showed that the Maasai pastoralists had perceived an increased number of hot days, daytime temperature, warm nights, and increased degree of coldness in the cold periods $[33,55]$.

\section{Variability and trends in annual maximum and minimum temperature}

Annual maximum $\left(\mathrm{T}_{\max }\right)$ and minimum $\left(\mathrm{T}_{\min }\right)$ temperature trends are illustrated in Fig. 4 and Fig. 5 , respectively. The highest annual $\mathrm{T}_{\max }$ of $25.93^{\circ} \mathrm{C}, \quad 26.38^{\circ} \mathrm{C}, \quad 25.87^{\circ} \mathrm{C}$ and $26.06^{\circ} \mathrm{C}$ was recorded in 1987, 2000, 2009 and 2011, respectively, while the lowest annual $\mathrm{T}_{\max }$ of $24.18^{\circ} \mathrm{C}, \quad 24.21^{\circ} \mathrm{C}, 23.33^{\circ} \mathrm{C}$ and $24.54^{\circ} \mathrm{C}$ was recorded in 1985, 1989, 1990 and 1998, respectively. On the other hand, the highest annual $\mathrm{T}_{\min }$ of $13.93^{\circ} \mathrm{C}, 14.16^{\circ} \mathrm{C}, 14.03^{\circ} \mathrm{C}$ and $14.10^{\circ} \mathrm{C}$ was recorded in years 1983, 2011, 2013 and 2014, respectively, while the lowest annual $\mathrm{T}_{\min }$ of $12.50^{\circ} \mathrm{C}, \quad 12.7^{\circ} \mathrm{C}, \quad 12.62^{\circ} \mathrm{C}$ and $12.64^{\circ} \mathrm{C}$ was recorded in years 1989, 1995, 1996 and 2003, respectively. Low-temperature variability was recorded for both $\mathrm{T}_{\max }$ and $\mathrm{T}_{\min }$; however, $\mathrm{T}_{\max }(\mathrm{CV}$
$=16 \%$ ) recorded a higher variability when compared to $\mathrm{T}_{\min }(\mathrm{CV}=3.5 \%)$. The linear regression line showed a positive slope for both the annual $\mathrm{T}_{\max }$ and $\mathrm{T}_{\min }$ trends with an annual rate of increase of $0.02^{\circ} \mathrm{C}$ and $0.03^{\circ} \mathrm{C}$, respectively. The trends for both the $\mathrm{T}_{\max }$ and $\mathrm{T}_{\min }$ were statistically significant (Table 5). Similar observations for Ghana have been reported by another study [32]. These results concur with other findings which have also shown that there is an increase in extreme temperature events such as warm days, warm nights, extreme $\mathrm{T}_{\max }$, and duration of warm spells $[1,56]$. The findings are also in agreement with the IPCC report, which predicted an average temperature rise of $0.2^{\circ} \mathrm{C}$ per decade in Kenya [57]. The results concur with the IPCC report which stated that trends of weather and climate events are increasingly deviating from the normal [1]. This includes higher $T_{\min }$ associated with warmer and fewer cold days and nights, and higher $\mathrm{T}_{\max }$ associated with warmer and more frequent hot days and nights over most land areas. With increasing trends in annual temperature, there is the need to understand how such trends will affect agricultural systems in the ASALs and how farmers will need to adjust to CC risks such as moisture and heat stress. Table 7 shows the absolute changes in seasonal and annual temperatures in Yatta from 1983 to 2014. The total increase in mean annual $\mathrm{T}_{\max }$ between 1983 and 2014 was $0.71^{\circ} \mathrm{C}$ while the mean $\mathrm{T}_{\min }$ increased by a rate of $0.89^{\circ} \mathrm{C}$ over the same period. The findings show that the absolute 
Table 5 Mann-Kendall test for seasonal rainfall and annual temperature.

\begin{tabular}{lllllll}
\hline Time series & No. years & Kendall's $(\mathbf{S})$ & Var. $(\mathbf{S})$ & Kendall's tau & $\boldsymbol{p}$-value & A \\
\hline Seasonal rainfall & & & & & & \\
MAM season & 32 & 167 & 3141 & 0.384 & $0.003^{*}$ & 0.05 \\
OND season & 32 & 117 & 3135 & 0.271 & $0.037^{*}$ & 0.05 \\
Annual temperature & & & & $0.003^{*}$ & 0.05 \\
Tmax & 32 & 167 & 3141 & 0.384 & $0.000^{*}$ & 0.05 \\
Tmin & 32 & 211 & 3141 & 0.485 & \\
\hline
\end{tabular}

Notes: * shows statistical significance at $P<0.05$

Table 6 Farmers' perceptions of changes in temperatures over the last 5 years $(n=354)$.

\begin{tabular}{lccccccc}
\hline \multicolumn{1}{c}{ Indicator variables } & $\begin{array}{c}\text { Strongly } \\
\text { disagree }\end{array}$ & Disagree & Not sure & Agree & $\begin{array}{c}\text { Strongly } \\
\text { agree }\end{array}$ & Mean & Mode \\
\hline Increased daytime temperatures & 7.06 & 5.37 & 8.76 & $46.89^{*}$ & 31.92 & 3.91 & 4 \\
Increased number of hot days & 5.65 & 15.25 & 13.84 & $42.66^{*}$ & 22.60 & 3.61 & 4 \\
Increased number of cold days & 13.28 & 22.32 & $31.36^{*}$ & 22.88 & 10.17 & 2.94 & 3 \\
Increased number of cold days & 18.64 & $31.36^{*}$ & 18.36 & 22.03 & 9.60 & 2.73 & 2 \\
Decreased number of hot days & $35.31^{*}$ & 35.03 & 12.71 & 11.58 & 5.37 & 2.17 & 1 \\
Increased daytime temperatures & 33.90 & $34.75^{*}$ & 18.64 & 7.34 & 5.37 & 2.16 & 2 \\
\hline
\end{tabular}

Note: values are expressed as percentage $(\%) ; *$ statistical significance at $P<0.05$

increase in temperature was higher for the $\mathrm{T}_{\min }$ as compared to the $\mathrm{T}_{\max }$ in both annual and seasonal time scales. Based on the seasonal mean, the $\mathrm{T}_{\max }$ recorded an absolute increase of $0.32^{\circ} \mathrm{C}$ and $0.31^{\circ} \mathrm{C}$ in the MAM and OND seasons, respectively, while $\mathrm{T}_{\min }$ recorded an absolute increase of $0.81^{\circ} \mathrm{C}$ and $0.93^{\circ} \mathrm{C}$ for the MAM and OND seasons, respectively. These results depict similar findings of Aduma et al. [58], which established that there was a higher increase in absolute $\mathrm{T}_{\min }$ compared to $\mathrm{T}_{\max }$ in the Amboseli ecosystem during 1960-2014.

\section{Comparing farmers perception with meteorological data}

Farmers' perceptions of seasonal rainfall showed decreasing rainfall trends, notable changes in rainfall timings and increased occurrence of unpredictable rainfall patterns in the area over the past five years. Farmers perceived a decrease in the duration of both OND and MAM rains with lateonset and early cessation of seasonal rainfall. The farmers' perceptions were verified by the analyzed historical trends, which depicted that the seasonal rainfall was highly variable over the analysis period (1983-2014). However, the analyzed rainfall trends showed that the amount of seasonal rainfall exhibited increasing trends in the two seasons, which was contrary to farmers' perceptions of decreasing seasonal rainfall trends. The analyzed trends showed that the OND season recorded higher rainfall amounts than the MAM season but the rate of increase was slightly higher in the MAM season which could be explained by the increased intensity of the MAM rains supported by the FGDs results. The increasing uncertainty of seasonal rainfall in terms of the period of occurrence and the amount received will notably have an impact on the smallholder farmers' livelihoods; this claim is validated by the fact that most respondents perceived increasing incidence of drought and food insecurity. This indicates that rainfall parameters (duration and intensity) and drought incidences are highly correlated with crop productivity. The findings of this study confirm other studies which have shown a dramatic decline in the average number of rainy days in Kenya's ASALs, especially during the short rains (OND season) [26, 29, 56]. This has been compounded with more intense rainfall experienced within a very short time. These studies further indicate that the MAM season in Eastern Kenya has become unreliable and on average, has significantly reduced to support a harvest or even livestock rearing. Similarly, other findings have shown notable changes in MAM season in Eastern Kenya with a significant decline in the amounts and increased intensity over short periods [52]. This is a clear indication that the farming systems in Kenya's ASALs face exposure to $\mathrm{CC}$ risks, which negatively impact the crop productivity. The reduction in crop yield will translate to increased food insecurity, malnutrition, and poverty levels. Most of the farmers' perceptions of temperature trends indicated that there was an increase in the number of hot days 
Table 7 A Summary of absolute increase in maximum and minimum temperature (1983-2014).

\begin{tabular}{|c|c|c|c|c|c|}
\hline Parameter & Period & Equation & Year & Recorded $\left({ }^{\circ} \mathrm{C}\right)$ & Change $\left({ }^{\circ} \mathrm{C}\right)$ \\
\hline \multirow{6}{*}{ Maximum } & Annual & $Y=24.855+0.0228 x$ & 1983 & 24.88 & 0.71 \\
\hline & & & 2014 & 25.58 & \\
\hline & OND & $Y=24.872+0.0099 x$ & 1983 & 24.88 & 0.31 \\
\hline & & & 2014 & 25.19 & \\
\hline & MAM & $Y=25.929+0.0103 x$ & 1983 & 25.94 & 0.32 \\
\hline & & & 2014 & 26.26 & \\
\hline \multirow{6}{*}{ Minimum } & Annual & $Y=12.855+0.0288 x$ & 1983 & 12.88 & 0.89 \\
\hline & & & 2014 & 13.78 & \\
\hline & OND & $Y=13.706+0.03 x$ & 1983 & 13.74 & 0.93 \\
\hline & & & 2014 & 14.67 & \\
\hline & MAM & $Y=14.160+0.0261 x$ & 1983 & 14.19 & 0.81 \\
\hline & & & 2014 & 15.00 & \\
\hline
\end{tabular}

and daytime temperatures. This is supported by the results of temperature trends, which showed that both annual $\mathrm{T}_{\max }$ and $\mathrm{T}_{\min }$ had increased over time during the analysis period (1981-2014). The increase in temperature is a clear indication that global warming is happening, which correlates with decreasing rainfall trends as well as increased occurrence of droughts in the area. Both the findings from the farmers' perceptions and the analyzed temperature trends correlate with other findings, which show that the average annual temperatures in Kenya have increased by $1.0^{\circ} \mathrm{C}$ since 1960 with an average rate of $0.1^{\circ} \mathrm{C}$ per decade $[16,17]$. Similar results showing substantial increase in both $\mathrm{T}_{\min }$ and $\mathrm{T}_{\max }$ in Kenya were also reported by some other researchers $[29,33,57,58]$.

\section{Conclusion and recommendations}

Analysis of the historical climate data revealed increasing seasonal rainfall and annual temperature trends. The MK test revealed statistically significant rainfall and temperature trends. Farmers' perceptions portrayed that climate variability was happening in the area with signals such as increasing daytime temperatures and the number of hot days, late-onset and early cessation of rainfall, increased incidences of drought, food insecurity and drying of seasonal rivers. The uncertainty in the timing of seasonal rainfall coupled with changes in duration and intensity of rainfall exposes the farming systems to poor planning of the cropping calendar, hence, affecting key farming activities like planting and harvesting [51]. Increasing temperatures are associated with an increased rate of evaporation, which affects crop growth leading to reduced productivity [51, 59]. The changing weather patterns imply that sustainable crop production is becoming a challenging task if farmers continue with 'business as usual' farming models. Understanding farmers' perception of climate variability and change and relating the perception to meteorological data has been termed as a viable pathway to better adaptation planning [10, 32]. Based on these findings, there is a need to focus on adaptation approaches that would counter the risks of the perceived changes in climate as well as noted climate trends and variability. There is a need to focus on integrating farmers' indigenous knowledge of current and experienced climate parameters with data from meteorological records to inform policy decisions for upscaling and adoption of sustainable adaptation responses. Such adaptation responses should include the provision of climate advisory services and reliable weather forecasts which can inform on the optimum crop growing windows thus minimizing losses from unplanned seasonal calendars.

To manage the experienced CC risks, farmers' adaptation should focus on transformative adaptation strategies, which require changes in the farming systems. Some of the viable adaptation strategies would be the adoption of climate-smart agriculture models such as drought-tolerant crops and/or crop varieties with shorter growing periods that would complement the shortened rainy periods. Besides, the adoption of water management strategies, such as water harvesting, would play a critical role in harnessing available and unutilized rainwater for use during the dry seasons. However, the analyzed seasonal rainfall trends showed an increase, which is contrary to other analyses conducted in Kenya's ASALs [12, $26,28,29,43]$; hence, this new finding may require further verification to ascertain its feasibility. Further research should focus on evaluating 
economic losses from CC and variability impacts, available resources and how these could be harnessed to build effective and sustainable adaptation for farmers in the ASALs zones of Kenya and other similar regions in Africa. Sustainable adaptation calls for an integrated system approach where all key stakeholders can play their role in building farmers' adaptive capacity.

\section{Acknowledgment}

The authors acknowledge the Mwalimu Nyerere African Union Female Scholarship Scheme and the Kenya National Research Fund for funding this study. The authors acknowledge the Kenya Meteorological Department for providing the temperature and rainfall data. The authors appreciate the support from the ward agriculture officials in the Yatta sub-County and all the respondents and discussants who participated in data provision through interviews and focus group discussions respectively.

\section{Conflict of Interest}

The authors declare that they have no conflict of interest

\section{References}

[1] IPCC Climate Change 2014. Impacts, Adaptation and Vulnerability. Contribution of working group II to the Fifth Assessment Report of the Intergovernmental panel on climate change; 2014.

[2] IPCC Summary of policymakers: Special report on 'managing the risks of extreme events and disasters to advance climate change adaptation. Cambridge: Cambridge University Press; 2011.

[3] FAO Climate Change and Food Systems: Global Assessments and Implications for Food Security and Trade, Food Agriculture Organization of the United Nations (FAO), Rome, 2015.

[4] Serdeczny O, Adama S, Baarsch F, Coumou D, Robinson A, Hare W, et al. Climate Change impacts in Sub-Saharan Africa: From physical changes to their social repercussions. Reg Environ Change 2017; 17:1585-1600.

[5] IPCC Managing the risks of extreme events and disasters to advance climate change adaptation (SREX). Special Report of the Intergovernmental Panel on Climate Change (IPCC), Geneva, IPCC Secretariat, 2012.

[6] Shiferaw B, Tesfaye K, Kassie M, Abate T, Prasanna $\mathrm{BM}$, Menkir A. Managing vulnerability to drought and enhancing livelihood resilience in sub-Saharan Africa: Technological, institutional and policy options. Weather Clim Extreme 2014; 3:67-79.
[7] Miyan MA. Droughts in Asian least developed countries: vulnerability and sustainability. Weather Clim Extreme 2015; 7:8-23.

[8] Lipper L, Thornton P, Campbell BM, Baedeker T, Braimoh A, Bwalya $M$, et al. Climate-smart agriculture for food security. Nat Clim Change 2014; 4:1068-1072.

[9] Adimassu Z, Kessler A. Factors affecting farmers' coping and adaptation strategies to perceived trends of declining rainfall and crop productivity in the central Rift valley of Ethiopia. Environ Syst Res 2016; 5:13.

[10] Cooper PJM, Dimes J, Rao KPC, Shapiro B, Shiferaw B, Twomlow S. Coping better with current climate variability in the rain-fed farming systems of subSaharan Africa: An essential first step in adapting to future climate change? Agric Ecosyst Environ 2008; 126:24-35.

[11] IPCC Global warming of $1.5^{\circ} \mathrm{C}$. An IPCC Special Report on the impacts of global warming of $1.5^{\circ} \mathrm{C}$ above pre-industrial levels and related global greenhouse gas emission pathways, in the context of strengthening the global response to the threat of climate change, sustainable development, and efforts to eradicate poverty. Masson-Delmotte V, Zhai P, Pörtner HO, Roberts D, Skea J, Shukla PR, et al. In Press, 2018 (eds).

[12] Gichangi EM, Gatheru M, Njiru EN, Mungube EO, Wambua JM, Wamuongo JW. Assessment of climate variability and change in semi-arid Eastern Kenya. Clim Change 2015; 130(2):287-297.

[13] Funk C, Eilerts G, Davenport F, Michaelsen J. A Climate Trend Analysis of Kenya: U.S. Agency for International Development, Washington, D.C; 2010.

[14] Lyon B, DeWitt DG. A recent and abrupt decline in the East African long rains. Geophys Res Lett 2012; 39(2):L02702.

[15] Liebmann B, Hoerling MP, Funk C, Bladé I, Dole RM, Allured D, et al. Understanding recent eastern horn of africa rainfall variability and change. J Climate 2014; 27:8630-8645.

[16] Wandiga SO, Opondo M, Olago D, Githeko A, Githui F, Marshall M, et al. Vulnerability to epidemic malaria in the highlands of Lake Victoria basin: the role of climate change/variability, hydrology and socioeconomic factors. Clim Change 2010; 99:473-497.

[17] McSweeney C, New M, Lizcano G. UNDP Climate Change Country Profile: Kenya, 2009, Available at http://ncsp.undp.org/sites/default/files/Kenya.oxford report.pdf [Accessed on 4/01/2019].

[18] Muema E, Mburu J, Coulibaly J, Mutune J. Determinants of access and utilization of seasonal climate information services among smallholder farmers in Makueni County, Kenya. Heliyon 2018; 4(11):e00889.

[19] Savo V, Lepofsky D, Benner JP, Kohfeld KE, Bailey J, Lertzman K. (2016). Observations of climate change among subsistence-oriented communities around the world. Nat Clim Change 2016; 6(5):462-473.

[20] Mafongoya PL, Ajayi OC, editors. Indigenous knowledge systems and climate change management in Africa. Wageningen, The Netherlands: CTA; 2017. 
[21] Myuri B, Obert J, Mafongoya P. Integration of indigenous and scientific knowledge in climate adaptation in KwaZulu-Natal, South Africa. Change Adapt Socio-ecol Syst 2017; 3(1):56-67.

[22] Ayanlade A, Radeny M, Morton JF. Comparing smallholder farmers' perception of climate change with meteorological data: a case study from Southwestern Nigeria. Weather Clim Extremes 2017; 15:24-33.

[23] Cuni-Sanchez A, Fandohan B, Assogbadjo A, Sinsin B. A countrywide multi-ethnic assessment of local communities' perception of climate change in Benin (West Africa). Clim Dev 2012; 4(2):114-128.

[24] Mutandwa E, Hanyani-Mlambo B, Manzvera J. Exploring the link between climate change perceptions and adaptation strategies among smallholder farmers in Chimanimani district of Zimbabwe. Int J Soc Econ 2019; 46(7):850-860.

[25] Abid M, Scheffran J, Schneider UA, Ashfaq M. Farmers' perceptions and adaptation strategies to climate change and their determinants: the case of Punjab province, Pakistan. Earth Syst Dyn 2015; 6:225-243.

[26] Recha CW, Makokha GC, Traore PS, Shisanya C, Lodoun T, Sako A. Determination of Seasonal Rainfall Variability, Onset and Cessation in semi-arid Tharaka district, Kenya. Theor Appl Climatol 2012; 108: 479494.

[27] Mugalavai EM, Kipkorir EC, Raes D, Rao MS. Analysis of rainfall onset, cessation and length of growing season for western Kenya. Agric For Meteorol 2008; 148:1123-1135.

[28] Babadoye AO, Ogara WO, Ouma GO, Onono JO. Comparative analysis of rainfall trends in different sub-counties in Kajiado County Kenya. Int J Innov 2014; 3(12):180-195.

[29] Chepkoech W, Mungai NW, Stöbe S, Bett HK, LotzeCampen H. Farmers' perspectives impact of climate change on African indigenous vegetable production in Kenya. Int J Clim Chang Strateg Manag 2018; 10(4):551-579.

[30] Limantol AM, Keith BE, Azabre BA, Lennartz B. Farmers' perception and adaptation practice to climate variability and change: a case study of the vea catchment in Ghana. SpringerPlus 2016; 5(1):830.

[31] Evelyn JM, Charles KN, Patricia M. Smallholder farmers' perceptions and adaptations to climate change and variability in Kitui County, Kenya. J Earth Sci Clim Change 2017; 8:389.

[32] Nuamah PA, Botchway E. Comparing smallholder farmers' climate change perception with Climate data: the case of Adansi North District of Ghana. Heliyon 2019; 5(12):e03065.

[33] Bobadoye AO, Ogara WO, Ouma GO, Onono JO. Pastoralist perceptions on climate change and variability in Kajiado in relation to meteorology evidence. Acad J Interdiscip Stud 2016; 5(1):37-46.

[34] MoALF. Climate Risk Profile for Machakos County. Kenya County Climate Risk Profile Series. The Ministry of Agriculture, Livestock and Fisheries (MoALF), Nairobi, Kenya; 2017, Available at https://cgspace.cgiar.org/bitstream/handle/10568/962 83/Machakosf_Climate_Risk_Profile_Final.pdf

[35] Yamane T. Statistics: An Introductory Analysis. 2nd ed. Harper and Row: New York; 1967.

[36] Newing H. Conducting Research in Conservation. A Social Science Perspective, Routledge: London; 2011.

[37] Ukhurebor, KE, Abiodun IC. Variation in annual rainfall data of forty years (1978-2017) for SouthSouth, Nigeria. JASEM 2018; 22(4):511-518.

[38] Oke IA, Ismai'l A. Trend analysis of precipitation in Birnin Kebbi, Nigeria. Res J Agric Sci 2012; 2(7):286-297.

[39] Jaiswal RK, Lohani AK, Tiwari HL. Statistical analysis for change detection and trend assessment in climatological parameters. Environ Process 2015; 2(4):729-749.

[40] Pingale SM, Khare D, Jat MK, Adaowski T. Trend analysis of climatic variables in an arid and semi-arid region of the Ajmer District, Rajasthan, India J Water Land Dev 2016; 28:3-18.

[41] Nalley D, Adamowski J, Khalil B, Ozga-Zielinski B. Trend detection in surface air temperature in Ontario and Quebec, Canada during 1967-2006 using the discrete wavelet transform. Atmos Res 2013; 132-133: 375-398.

[42] Araya A, Stroosnijder L. Assessing drought risk and irrigation need in northern Ethiopia. Agric For Meteorol 2011; 151(4):425-436.

[43] Gichangi EM, Gatheru M. Farmers' awareness and perception of climate change and the various adaptation measures they employ in the semi-arid eastern Kenya. Clim Change 2018; 4(14):112-122.

[44] Kashaigili JJ, Levira P, Liwenga E, Mdemu MV. Analysis of climate variability, perceptions and coping strategies of Tanzanian coastal forest dependent communities. Am J Clim Change 2014; 3:212-222.

[45] Stöber S, Chepkoech W, Neubert S, Kurgat B, Bett H, Lotze Campen H. Adaptation pathways for African indigenous vegetables' value chains. In: Leal Filho W, Belay S, Kalangu J, Menas W, Munishi P, Musiyiwa K. (eds). Climate Change Adaptation in Africa, Clim Change 2017; pp. 413-433.

[46] Kalungu JW, Filho WL, Harris D. Smallholder farmers' perception of the impacts of climate variability and change on rain-fed agricultural practices in semi-arid and sub-humid regions of Kenya. Environ Earth Sci 2013; 3(7):129-140.

[47] Kahsay HT, Guta DD, Birhanu BS, Gidey TG. Farmers' perceptions of climate change trends and adaptation strategies in semiarid highlands of Eastern Tigray, Northern Ethiopia. Adv Meteorol 2019; 3849210.

[48] Lema MA, Majule AE. Impacts of climate change, variability and adaptation strategies on agriculture in semi-arid areas of Tanzania: the case of Manyoni District in Singida region, Tanzania. Afr J Environ Sci Technol 2009; 3(8):206-218.

[49] Fadina AMR, Barjolle D. Farmers' adaptation strategies to climate change and their implications in the Zou Department of South Benin. Environments 2018; 5(1):15. 
[50] Okonya SJ, Syndikus K, Kroschel J. Farmers' perception of and coping strategies to climate change: evidence from six agro ecological zones of Uganda. J Agric Sci 2013; 5(8):252-263.

[51] Ukhurebor KE, Siloko IU. Temperature and rainfall variability studies within South-South region of Nigeria. AU eJIR 2020; 5(2):1-19.

[52] Awuor C. Increasing drought in arid and semi-arid Kenya. In: Ensor J, Berger R. (eds.), Understanding climate change adaptation: Lessons from communitybased approaches. Practical Action Publishing, Rugby; 2009, pp. 101-114.

[53] Conway D, Schipper ELF. Adaptation to climate change in Africa: Challenges and opportunities identified from Ethiopia. Glob Environ Change 2011; 21(1):227-237.

[54] Aberra Y. Perceptions of climate change among members of the house of people's representatives, Ethiopia. J Risk Res 2012; 15(7):771-785.

[55] Filho LW, Nzengya D, Muasya G, Chemuliti J, Kalungu JW. Climate change responses among masaai community in Kenya. Clim Change 2017; 145(1):7183.

[56] Omondi PA, Awange JL, Forootan E, Ogallo LA, Barakiza R, Girmaw GB, et al. Changes in temperature and rainfall extremes over the Greater Horn of Africa region from 1961 to 2010. Int J Climatol 2013; 34(4):1262-77.

[57] IPCC Climate Change 2014. Synthesis Report. Contribution of Working Groups I, II and III to the Fifth Assessment Report of the Intergovernmental Panel on Climate Change [Core Writing Team, Pachauri RK, Meyer LA. (eds.). Geneva, Switzerland 2014 a; 151 pp.

[58] Aduma MM, Ouma GO, Said MY, Wayumba GO, Muhwanga J. Spatial and Temporal Trends of Rainfall and Temperature in the Amboseli Ecosystem of Kenya. World J Innov Res 2018; 5(5):28-42.

[59] Muluneh A, Bewket W, Keesstra S, Stroosnijder L. Searching for evidence of changes in extreme rainfall indices in the central rift valley of Ethiopia. Theor Appl Climatol 2017; 128(3-4):795-809. 